\title{
Coaching Clinic Basic Movements and Dominant Physical Conditions for Athletes at Gemilang Raya FC
}

\author{
Boby Agustan, Didi Muhtarom, Oman Hadiana, Dani Nurdiansyah, Elang Fauzan
}

\author{
STKIP Muhammadiyah Kuningan \\ Email: bobyagustan@upmk.ac.id 085793704148
}

\begin{abstract}
Basic movements and dominant physical conditions are often still a problem for soccer players in supporting the strategies and tactics of a coach in building attacks or in defense, especially at Football Club Gemilang Raya Kuningan. Some players still have shortcomings in carrying out correct and accurate basic movements and do not yet know the physical procedural requirements that a professional soccer player must possess. Based on the problems faced, the STKIP Muhammadiyah Kuningan Service Team carried out activities to overcome the problems faced by partners. Community service activities aim to improve the abilities and skills of Football Club Gemilang Raya Kuningan athletes in performing basic movements and knowing the dominant physical condition. The activity was carried out at the Gemilang Raya Kuningan Football Club and was attended by 20 players. The method used is a coaching clinic which consists of 2 sessions. The material provided consists of understanding basic movements and dominant physical conditions, practice on basic movements and dominant physical conditions. The results of the activity to the community showed an increase in the abilities and skills of Football Club Gemilang Raya Kuningan players regarding basic movements and dominant physical conditions.

Keywords: Coaching Clinic, Basic Movement, Dominant Physical Condition, Football Club
\end{abstract}

\section{INTRODUCTION}

Football is a form of team sport consisting of eleven players including a goalkeeper. Football is a very popular game. Football games are often played by children, adults and parents. The goal of the game of soccer is that each team or team tries to control the ball, put the ball into the opponent's goal as much as possible, and try to break the opponent's attack to protect or keep the goal from conceding the ball. Football is a team game that requires basic cooperation between team members, as one of the characteristics of the game of football (Iskandar and Agustan, 2018).

The basis of cooperation between fellow team members or between players requires good basic techniques so that the game can run according to the strategies and tactics of the coach (Jumhana and Agustan, 2016). Therefore, it is necessary to have a good understanding and must be owned by every player in a soccer team. The game will run smoothly if the basic movements are well owned by each player, the strategy and tactics of a coach, and most importantly to support this requires excellent dominant physical conditions (Jumhana and Agustan, 2016).

Games in any sport, be it individual or team sports are largely determined by the factors that can increase the success of achieving their goals, both from within the body or from the surrounding environment. These factors include: strategy, tactics, physical and mental, mental, biomotor (physical), psychomotor, anthropometry, motivation, nutrition, genetics and others (Putra; R.T., 2021). So that in sports games aspects of basic motion and physical condition are needed to achieve the desired goal.

The obstacles in carrying out the coach's instructions are not only limited to the tactics and strategies that are carried out, but there are several things that are important for every athlete. Every player has basic moves, but the quality of the basic moves has not yet emerged so the game cannot run according to tactics and strategy. This will determine the performance of each player. Performance is shown by each player based on the abilities possessed by each player in a match (Agustan, Kusmaedi and Hendrayana, 2020). Not only that, the dominant physical condition aspect must be known by players with the aim of knowing how to maintain and improve it. This can not be separated from one another, so that the achievement of an athlete in the game of football can increase (Mahendra, Sugiyarto and Kiyatno, 2014). The lack of attention to aspects of the dominant physical condition of a player, football achievements in Indonesia are less than optimal as expected. This is marked by the condition of 
the athlete getting tired quickly in a certain time, the basic movement ability decreases before the match ends, and so on.

Football Club (FC) Gumilang Raya Kuningan is one of the amateur football club schools in Kuningan Regency, West Java which has good management and achievements. With various achievements and management achieved, this football club also has important problems that need to be resolved. The problem is regarding players' understanding of the importance of knowing good basic movements and understanding of the importance of having dominant physical conditions in athletes which can then be used as aspects in achieving achievements.

Based on interviews conducted with the owner of FC Gemilang Raya, Bripka Arif Eka Hidayat, information was obtained that many of these players still have difficulty in understanding the importance of having basic movement skills and dominant physical conditions to achieve even more prestigious achievements. together, and with this dedication, we hope to find a solution for joint progress between STIKP Muhammadiyah Kuningan and FC Gemilang Raya Kuningan.

Based on these problems, it is necessary to have a Coaching Clinic activity for FC Gemilang Raya regarding the importance of understanding basic movement abilities and dominant physical conditions in determining achievement. STKIP Muhammadiyah Kuningan seeks to conduct a Coaching Clinic for athletes or players of FC Gemilang Raya Kuningan. Pengabdian kepada Masyarakat (PKM) is that the players have an understanding and care about good basic movement skills and have the ability to understand aspects of the dominant physical condition in order to improve better performance.

\section{MATERIALS AND METHODS}

Coaching Clinic basic movements and dominant physical conditions in the soccer game at the Gemilang Raya Kuningan Football Club followed by 20 players. The activity was carried out for two days, on 19 and 20 June 2021 from 08.00-12.00 WIB every day.

The implementation activities is carried out through several stages and methods, including::

1. Interview with the head of the club owner and the coach of FC Gemilang Raya regarding the importance of understanding basic movements and dominant physical conditions in achieving better performance.

2. Coordinating the technical implementation of the Coaching Clinic activities that will be conveyed to players, regarding the importance of understanding basic movements and dominant physical conditions.

3. The Coaching Clinic Method. It is carried out by delivering material first on the first day by the service team to FC Gemilang Raya players, then on the second day there is practice on basic movements and dominant physical conditions.

4. Overall activity evaluation stage carried out by the service team, owner and coach of FC Gemilang Raya as well as discussing activities at the next stage.

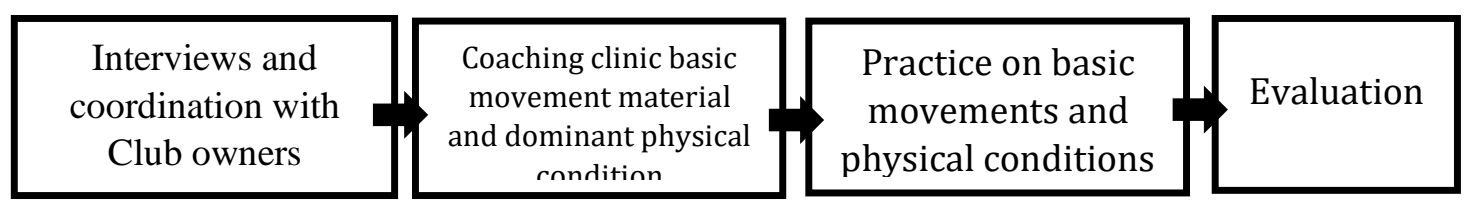

Figure 1. Implementation Method

Coordination of activities was carried out by a service team from STKIP Muhammadiyah Kuningan with the owner and trainer of FC Gemilang Raya with the aim of discussing the technical and material to be delivered at the coaching clinic.

\section{RESULT}

The Pengabdian kepada Masyarakat (PKM) activities with the theme Coaching Clinic basic movements and dominant physical conditions in soccer games at the Gemilang Raya Kuningan Football Club began with the preparation of the committee from the STKIP Muhammadiyah 
Kuningan service team, then participants filled out the attendance list provided. The process of filling out the attendance list is carried out by prioritizing health protocols.

The next stage is, after the participants enter the coaching clinic room, the PKM activities are continued with an opening ceremony which is attended by the service team, club owners, coaches and all athletes. This activity can be seen in Figure 2 below.

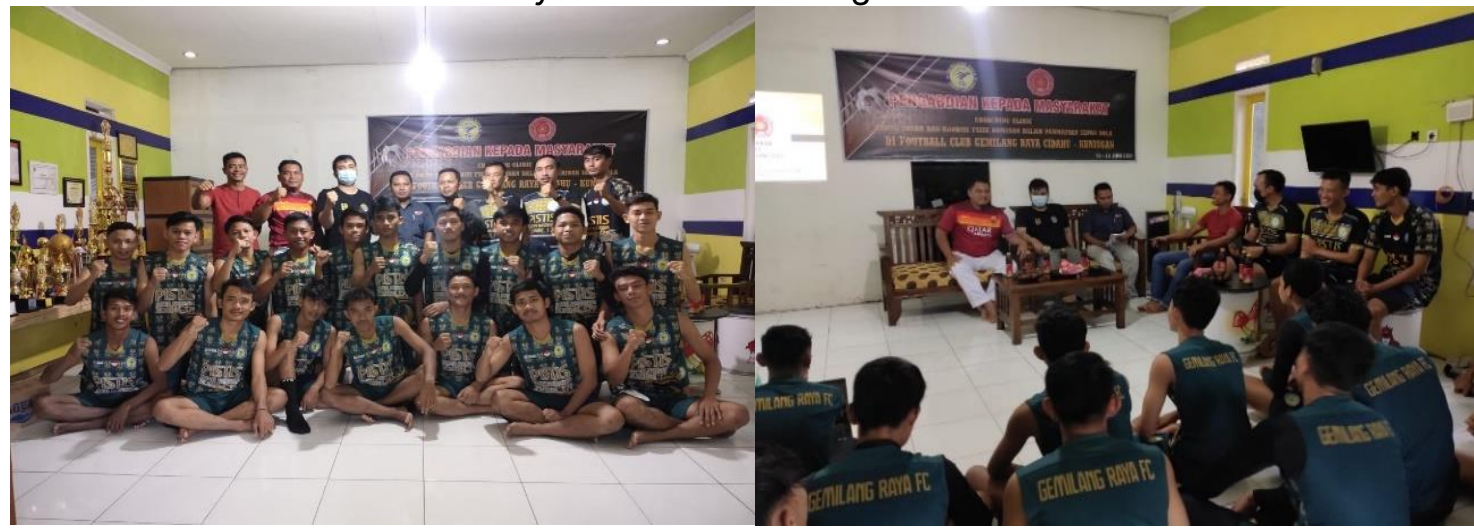

Figure 2. Coaching Clinic Materials and Group Photos

Figure 2 above is the initial training activity. Starting with participants filling out the attendance list, then the activity was opened by the owner of FC Gemilang Raya, Bripka Arif Eka Hidayat. This was followed by the coaching clinic participants listening to the material delivered by the resource persons and the service team regarding the importance of understanding basic movements and dominant physical conditions.

The next stage or on the second day, the resource team and the service team carried out practical activities in the field directly to the players with the aim of knowing how far the athletes understood the material that had been delivered at the coaching clinic on the first day. The details of the activities are shown in Figure 3 and Table 1. Below:

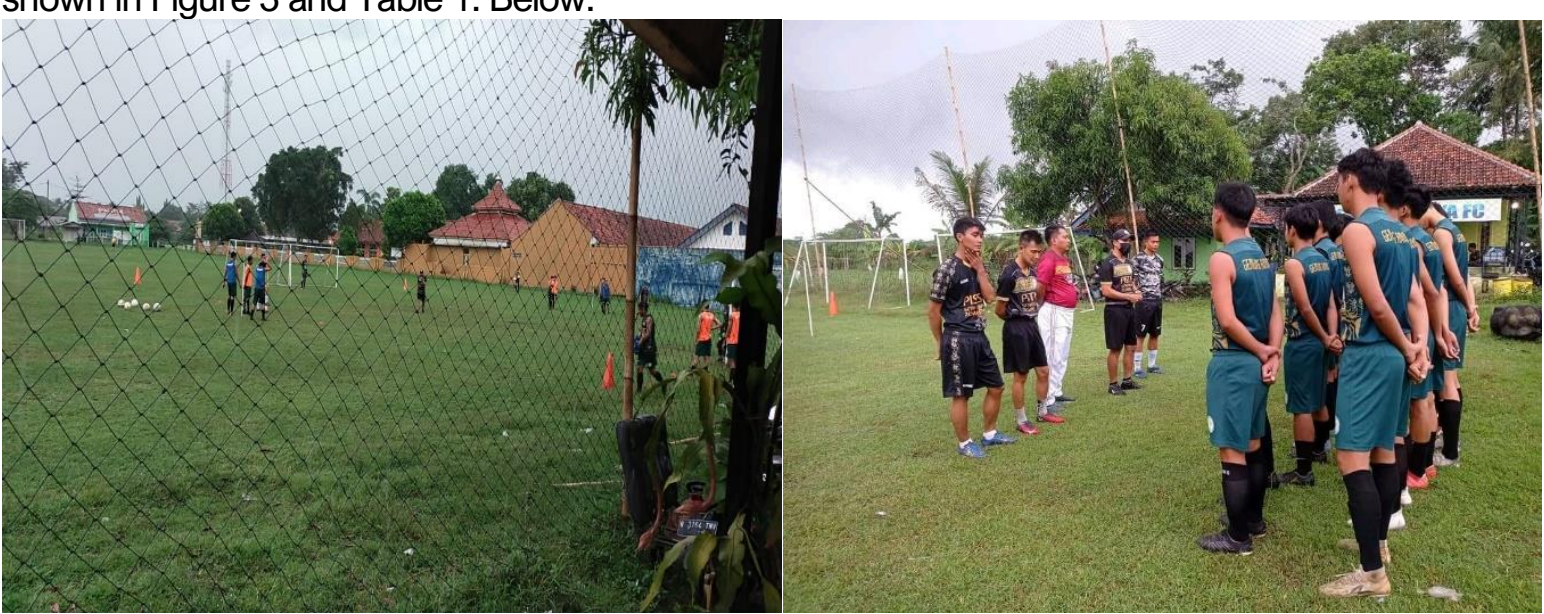

Figure 3. Delivery of Training Materials by the Service Team

\section{DISCUSSION}

In the discussion, there are several stages carried out in community service as attached in the following table:

Table 1. Coaching Clinic Activity Series

\begin{tabular}{|c|c|}
\hline Kegiatan & Uraian \\
\hline Coaching Clinic & The coaching clinic activity with the delivery of material by the \\
\hline $\begin{array}{l}\text { Day } 1=\text { Submission of } \\
\text { Materials in the Room }\end{array}$ & $\begin{array}{l}\text { service team was carried out on the first day with the seminar or } \\
\text { lecture method. The material presented is: }\end{array}$ \\
\hline
\end{tabular}


Coaching Clinic

Day 2 = Practice in the Field

Evaluation
2. Definition of dominant physical condition

3. The importance of understanding basic movements

4. The importance of understanding the dominant physical condition

The implementation of activities on the second day is carried out after participants have finished participating in the program on the first day. The second day of the coaching clinic was carried out by the service team to the participants by way of direct practice in the field with the direction of the service team.

In this activity, players practice hands-on with the guidance of a service team to be able to practice how to perform quality basic movements and be supported by understanding the dominant physical condition. At this stage, participants have begun to increase their understanding so that they can be practiced later.

Evaluation is carried out to measure the level of success of activities, as well as to identify obstacles and problems that occur. The evaluation is carried out by the service team and in coordination with the club.

At this evaluation stage, it also discusses the next program that will be carried out, as a follow-up reference for training activities.

Based on the results of the coaching clinic activity (delivery of material in class and practice in the field), then ending with an evaluation it can be seen that FC Gemilang Raya players have considered this coaching clinic important as a material for deepening knowledge for each player in an effort to improve achievement in a game. football team. Basic movement skills and aspects of dominant physical condition are very important for every soccer player (Bafirman, H.B dan Wahyuri, 2018). The results of the training also showed an increase in knowledge and athletes in understanding the importance of quality basic movements and dominant physical conditions. In addition to an increase, other findings from this activity were also obtained, including how many athletes still do not understand how to perform these quality basic movements, and only know how to perform basic movements.

\section{CONCLUSIONS AND SUGGESTIONS}

Pengabdian kepada Masyarakat (PKM) activities in the form of a Coaching Clinic, basic movements and dominant physical conditions in the soccer game at the Gemilang Raya Kuningan Football Club as a whole can run smoothly and well. All participants enthusiastically participated in the training activities from start to finish. The PKM activity was attended by 20 FC Gemilang Raya players. The results obtained from this PKM activity are increased understanding and skills of players or athletes about the importance of having quality basic movement abilities and understanding and having dominant physical conditions in soccer games. At the next stage, it is hoped that players can start applying it to every practice or during a match.

Suggestions for the next activity, namely Coaching Clinic activities can be done programmatically. So that players are getting used to doing quality basic movements. Understand the importance of the dominant physical condition for each player to be able to support the coach's takkit and strategy.

\section{INFINITE GRATITUDE}

Infinite gratitude goes to LPPM STKIP Muhammadiyah Kuningan which has funded community service activities in 2021. Not to forget to thank the management and staff and players of the Gemilang Raya Kuningan Football Club for their participation and assistance so that this community service activity can be carried out. running smoothly. 


\section{REFERENCES}

Agustan, B., Kusmaedi, N. and Hendrayana, Y. (2020) 'Modifikasi pembelajaran : hybrid sport education-invasion games competence model terhadap performa permainan bola basket', 6(1), pp. 157-172.

Bafirman, H.B dan Wahyuri, A. . (2018) Pembentukan Kondisi Fisik.

Iskandar, Y. and Agustan, B. (2018) 'Pengaruh Pendekatan Taktis Terhadap Keterampilan Passing Bola Pada Sekolah Sepakbola Turangga Sakti', JUARA : Jurnal Olahraga, 3(1), p. 8. doi: 10.33222/juara.v3i1.211.

Jumhana, J. and Agustan, B. (2016) 'Pengaruh Model Direct Instruction Terhadap Teknik Dasar Dribbling Dalam Permainan Sepak Bola', JUARA: Jurnal Olahraga, 1(1), p. 46. doi: 10.33222/juara.v1i1.57.

Mahendra, I. R., Sugiyarto, S. and Kiyatno, K. (2014) 'Faktor Kondisi Fisik Dominan Penentu Prestasi Bermain Tenis Meja (Analisis Faktor Fleksibilitas Pergelangan Tangan, Fleksibilitas Pinggul, Waktu Reaksi, Koordinasi Mata Tangan, Kelincahan , dan Power Otot Lengan Pada Mahasiswa Pembinaan Prestasi Tenis Mej', Indonesian Journal of Sports Science, 1(1), pp. 1-13.

Putra; R.T., K. S. (2021) 'Analisis Faktor Biomotor Dan Psikomotor Dominan Penentu Kemampuan Groundstroke Forehand Tenis Lapangan', pp. 408-416. 